Journal of the Operations Research Society of Japan

Vol. 45, No. 4, December 2002

\title{
配当のある年金保険商品に対応する
}

保険会社の最適ポートフォリオ戦略

\author{
湯前祥二 \\ ニッセイ基礎研究所
}

(受理 2001 年 7 月 27 日；再受理 2002 年 6 月 19 日)

\begin{abstract}
和文概要 年金保険商品を，(1) 会社の運用資産を，原資産とする (2) コールオプション類似の条件付き請 求権として，モデル化した。期末の運用資産を，会社持ち分と契約者持ち分に分け，会社は，運用戦略によっ て原資産に影晦を与えることで，会社持ち分を最適化するとした。無裁定条件を課して，マルチンゲール法を 使って，会社持ち分の最適化（収益率の分散最小化）を行った結果，期末の資産価値を表す式は，危険資産の 期末の価格に応じて，3つの区間に分かれることが分かった。また，最適な資産ポートフォリオ過程が得られ た．さらに，数値計算によって，会社持ち分の効率的フロンティアを得た。
\end{abstract}

1. はじめに

生命保険会社が一般勘定で扱う企業年金保険商品には,

- 最低利率保証があり,

・かつ, 運用成果が芳しい場合には, 配当が支払われる, という特徵があり，契約者側から見たペイオフは,コール・オプション類似である。した がって，年金保険商品を条件付き請求権として価格評価できる可能性がある。

しかし，年金保険商品には，

- 条件付き請求権の原資産が, 保険会社の運用戦略（ポートフォリオ構成）に依存する,

・複数年契約で, 契約が継続しながら，毎年，成果配当が行われる，

・配当額は, 配当時点以前では厳密には分からない, といった，通常のオプション（たとえば株価指数オプション）と異なる点も多い.これらの 年金保険商品独自の性質は，商品の価格評価や会社の最適投資戦略に大きく影響するはずで ある。

年金保険商品を条件付き請求権として調べたこれまでの研究には，以下のようなものが ある. Brennanと Schwartz [4] は，保険商品と, ヨーロピアンコールオプションの類似性を 認識して, BlackとScholes [3] のオプション理論を使って，現在価值を評価した。湯前 [15] は,「契約が継続しながら，毎年，成果配当が行われる」点に着目して，保険商品を，1年毎 に最大 5 回権利行使が可能な満期 5 年の条件付き請求権としてモデル化し, 準モンテカルロ 法で，現在価值を評価した。 Jensen と Jørgensen, Grosen [9]は，資産ポートフォリオが幾 何ブラウン運動するとして, 有限差分法を用いて, 経路依存の有配当保険の価值を評価し た. Miltersen と Persson [12]は, ベンチマークポートフォリオの収益率が正規分布すると 仮定して, 収支相当が成り立つような, 保証利率および公正な剩余の配分率の組み合わせ を得た. Giraldiら [5]は，保険商品に組み込まれたプットオプションの，ダイナミックヘッ 
ジング戦略を示した。ただし，オプションの原資産である，危険資産からなるポートフォリ オについて, 構成比率が変化しないと仮定した. Bacinello [2] は, 保険会社が操作できる変 数が，(1) 保証利率，(2) 配当の払い出し率，(3) 参照ポートフォリオのボラティリティ，の 3 つであることを示し，これら変数のうち 2 つを与えたとき，残りの 1 つがユニークに決ま る必要十分条件を得た。たたし，参照ポートフォリオは，幾何ブラウン運動するとした。

これらの研究を受けて，本論文では，年金保険商品の特異な性質のうち，「原資産が会社 の運用戦略依存である」ことを明示的に取り扱って，分析を行った。会社の運用戦略は，契 約終了時 (期末) の運用資産価值を左右し，契約者への配当と，期末の会社の持ち分（運 用資産価值から契約者の持ち分を差し引いた額）に影響を与える。したがって，会社が運 用戦略を適切に選択することで，期末の会社持ち分を最適化する方法を探った. Jensen と Jørgensen, Grosen [9], Miltersen と Persson [12]，および Bacinello [2] が，資産ポートフォ リオの変動プロセスを外部から与えたのに対し，本論分では，無危険資産と危険資産から なる内部構造を持つ資産ポートフォリオを考えた。さらに，Giraldiら [5]が一定とした，才 プションの原資産となるポートフォリオの資産構成について，会社が連続的に操作するとし て，保険契約を分析した。

最適運用戦略（最適配当戦略）の分析には，Karatzas ら [10]が最適ポートフォリオ選択問 題を解くのに用いた，マルチンゲール法を使った1。マルチンゲール法は，無裁定を仮定し，

1. 期末の根元事象ごとの期末の運用資産価值を, 無裁定の条件の下で, 最適となるよう に決める。

2. そのような期末の運用資産価值を実現する等価ポートフォリオを求める. という2つの段階に分けて，最適ポートフォリオ過程を得る方法である。連続時間の最適な ポートフォリオを直接求めるのは，一般には難しい。しかし，マルチンゲール法では，比較 的容易な期末の運用資産価値の最適化を行うことで, 最適ポートフォリオ過程が間接的に得 られる。

本論文でも，企業年金保険商品について，まず，期末の運用資産価值について，目的を分 散最小化とした最適化を行い，次いで，それを実現する最適ポートフォリオ過程を得た。ま た，数値計算によって，期末の会社持ち分について，効率的フロンティアを得た。その結果， 期末の資産価值を表す式は，危険資産の期末の価格に応じて，3つの区間に分かれることが 分かった。また，会社の最適化の結果が「確率 1 で配当しない」戦略であれば，有配当商品 の存在価値そのものを再検討しなければならない。しかし，本論文で設定した諸条件の下で の最適戦略では，配当する確率が正になることが分かった。

次節以降は，次のように構成されている。まず，第 2 節では，最低利率保証及び成果配当 付きの商品，および市場のモデルを定める．モデルには，無裁定の条件を付加する．第 3 節 と第 4 節で，マルチンゲール法による最適化を行う。まず，第 3 節で会社の期末持ち分を最 適化する。次に，第 4 節で，そのような期末持ち分を実現する運用戦略を明らかにする。さ らに会社の期末持ち分の効率的フロンティアを求める。第 5 節では，前提条件を設定し，具 体的な数值計算を行う。第 6 節では，まとめと今後の課題についての節である.

\section{2. モデル}

最低利率保証及び成果配当付きの商品を，次のような，会社と契約者の 2 者間の契約とし てモデル化しよう.

\footnotetext{
${ }^{1}$ Karatzas ら [10] 定理 3.7.6を参照.
} 


\section{1. 運用資産過程と契約者持ち分，会社持ち分}

満期を所与の $T, T>0$ とする連続時間 $t \in[0, T]$ を考える. 時刻 0 で，契約者は $\Pi_{L}(0) を$ 拠出し，会社は $\Pi_{L}(0)$ に自己の拠出 $\Pi_{E}(0)$ を加えて運用の原資 $\Pi_{A}(0)$,

$$
\Pi_{A}(0)=\Pi_{E}(0)+\Pi_{L}(0)
$$

とする. $\Pi_{L}(0), \Pi_{E}(0), \Pi_{A}(0)$ は全て所与で正の定数とする.

$t \in[0, T]$ の間，会社は，この当初価值 $\Pi_{A}(0)$ の資産を運用する. 運用の対象となる資産 クラスは，無危険資産と危険資産の 2 資産クラスとする。このうち, 無危険資産の価格過程 $\{B(t) ; t \geq 0\}$ は

$$
\frac{d B(t)}{B(t)}=r_{f} d t, \quad t \geq 0
$$

にしたがい，一方，危険資産の価格過程 $\{S(t) ; t \geq 0\}$ は

$$
\frac{d S(t)}{S(t)}=\mu d t+\sigma d W(t), \quad t \geq 0
$$

にしたがうとする。ただし， $r_{f}, \mu, \sigma$ は全て所与の正の定数であって， $r_{f}$ は無危険資産の 収益率， $\mu$ は危険資産の期待収益率， $\sigma$ は危険資産のボラティリティを表す。また， $W:=$ $\{W(t) ; t \in[0, T]\}$ は, 所与の観測確率空間 $(\Omega, \mathcal{F}, P)$ 上の標準ブラウン運動である. $\{x(t) ; t \in$ $[0, T]\}$ を危険資産への投資単位数の過程とすると，運用資産価值の過程 $\Pi_{A}:=\left\{\Pi_{A}(t) ; t \in\right.$ $[0, T]\}$ は,

$$
d \Pi_{A}(t)=\left(\Pi_{A}(t)-x(t) S(t)\right) \frac{d B(t)}{B(t)}+x(t) d S(t), \quad t \in[0, T]
$$

にしたがう。

時刻 $T$ での契約者の持ち分 $\Pi_{L}(T)$ は，

$$
\Pi_{L}(T)=\Pi_{L}(0) \max \left(e^{r_{g} T}, 1+\beta \frac{\Pi_{A}(T)-\Pi_{A}(0)}{\Pi_{A}(0)}\right)
$$

とする．ただし， $r_{g}$ は保証利率を表す所与の正の定数， $\beta \in(0,1]$ は払い出し率を表す所与 の定数である。すなわち，時刻 0 から時刻 $T$ への資産額の増加率に応じて，契約者に対し

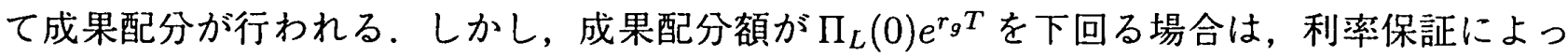
て， $\Pi_{L}(0) e^{r_{g} T}$ が時刻 $T$ の契約者持ち分となる（図 1).また，時刻 $t \in(0, T)$ では，契約者 への払い出しを行わないとする.

このとき，時刻 $T$ での会社の持ち分 $\Pi_{E}(T)$ は， $\Pi_{A}(T)$ から $\Pi_{L}(T)$ を契約者に払い出した 残り,

$$
\Pi_{E}(T)=\Pi_{A}(T)-\Pi_{L}(T)
$$

である. $\Pi_{A}(T)<\Pi_{L}(0) e^{r_{g} T}$ の場合は, $\Pi_{E}(T)<0$ となるが，会社は，自己資本から差額の $\Pi_{L}(0) e^{r_{g} T}-\Pi_{A}(T)$ を補填して，契約者へ保証した額を払い出すものとする ${ }^{2}$.

\footnotetext{
${ }^{2}$ 会社が $\Pi_{A}(T)$ を限度に契約者へ払い出すモデルでは，保険会社の自己资本からの補填は不要だが，契約 者への利率保証が損なわれる。一方，保険会社の自己資本から補填されるモデルでは，利率保証は損なわれな w.
} 


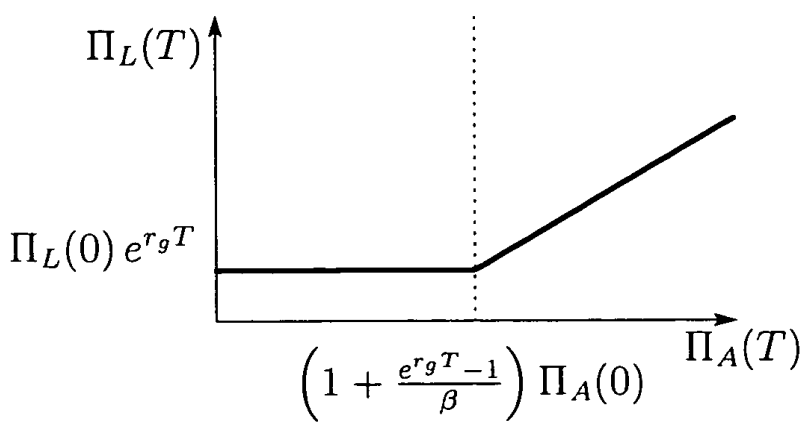

図 1: $\Pi_{A}(T)$ と $\Pi_{L}(T)$ の関係

\section{2. 運用資産過程の無裁定条件}

「資産額 0 から出発して, 途中及び期末の資産額が非負で，期末の資産の期待值が正とな る」ような運用戦略があるとき，これを裁定機会という。裁定機会が存在しないとき, 無裁 定機会，あるいは単に無裁定であるという。経済均衡が存在するためには，無裁定でなけれ ばならない。したがって，以下のようにして，モデルに無裁定条件を付ける.

$\left\{\mathcal{F}_{t} ; t \in[0, T], \mathcal{F}_{T}=\mathcal{F}\right\}$ を $W$ から生成される完備化フィルトレーションとして，任意の $(\Omega, \mathcal{F})$ 上の確率測度 $R$ について,

$$
\mathbb{E}_{t}^{R}[\cdot]:=\mathbb{E}^{R}\left[\cdot \mid \mathcal{F}_{t}\right], \quad t \in[0, T]
$$

を確率測度 $R$ の下での $\mathcal{F}_{t}$ 条件付き期待值とする。また，

$$
\mathbb{E}^{R}[\cdot]:=\mathbb{E}_{0}^{R}[\cdot]
$$

とする。

定義 2.1 (リスク中立確率測度) $(\Omega, \mathcal{F})$ 上の $P$ と同值な確率測度 $Q$ が, 任意の資産価值過 程 $\Pi_{A}$ に対して,

$$
\frac{\Pi_{A}(t)}{B(t)}=\mathbb{E}_{t}^{Q}\left[\frac{\Pi_{A}(T)}{B(T)}\right], \quad t \in[0, T]
$$

を満たすとき，この $Q$ をリスク中立確率測度という。

定義 2.2 (等価ポートフォリオ) ある条件付き請求権について，まったく同一のキャッシュ フローをもたらす運用戦略（ポートフォリオ）を，等価ポートフォリオという.

定義 2.3 (自己資金調達取引戦略) 運用戦略 $\left(\theta_{b}, \theta_{s}\right):=\left\{\left(\theta_{b}(t), \theta_{s}(t)\right), t \in[0, T]\right\}$ が,

$$
\begin{aligned}
& \theta_{b}(t) B(t)+\theta_{s}(t) S(t) \\
= & \theta_{b}(0) B(0)+\theta_{s}(0) S(0)+\int_{0}^{t} \theta_{b}(u) d B(u)+\int_{0}^{t} \theta_{s}(u) d S(u)
\end{aligned}
$$

を満たすとき, $\left(\theta_{b}, \theta_{s}\right)$ を, $\{(B(t), S(t)): t \in[0, T]\}$ に関する自己資金調達取引戦略という. このとき, 次の定理が成り立つ. 
定理 2.1 無裁定であり, かつ条件付き請求権の等価ポートフォリオとなる自己資金調達取 引戦略が存在するとする。このとき,リスク中立確率が存在し, かつ, 条件付き請求権の時 刻 $t$ での価格は，無危険利子率で割り引いた将来キャッシュフローのリスク中立確率の下で の $\mathcal{F}_{t}$ 条件付き期待值で与えられる.

証明：岩城 [8] 定理 1.3, 定理 1.4 を参照（証明終わり）.

このモデルの不確実性は $W$ のみから生じる.したがって, $\{\phi(t) ; t \in[0, T]\}$ を

$$
\begin{aligned}
\phi(t) & :=\exp \left(-\xi W(t)-\frac{1}{2} \xi^{2} t-r_{f} t\right), \quad t \in[0, T], \\
\xi & :=\frac{\mu-r_{f}}{\sigma}
\end{aligned}
$$

と定義すると, 次の定理が成り立つ.

定理 2.2 すべての $\mathcal{B} \in \mathcal{F}$ に対して

$$
Q(\mathcal{B}):=\mathbb{E}^{P}\left[\exp \left(r_{f} T\right) \phi(T) 1_{\{\mathcal{B}\}}\right]
$$

で定義される $\mathcal{F}$ から実数への関数 $Q$ は, リスク中立確率測度となる.

証明：岩城 [8] 定理 2.2 を参照（証明終わり）.

以下では, $x(t) S(t)$ が， $Q$ のもとで 2 乗可積分とする.このとき，次の命題が成り立つ. 命題 $2.1 \Pi_{A}(t) / B(t)$ は, $Q$ のもとでマルチンゲールである.すなわち,

$$
\frac{\Pi_{A}(t)}{B(t)}=\mathbb{E}_{t}^{Q}\left[\frac{\Pi_{A}(T)}{B(T)}\right], \quad t \in[0, T] \text {. }
$$

証明： $\Pi_{A}$ が自己資金調達取引戦略によって運用されている資産価值の過程であるので, 明 らか.(証明終わり).

\section{3. 会社持ち分の最適化}

この節では，前節のモデルを前提に，マルチンゲール法の第 1 段階（期末の最適化）を行 う. 第 2 段階（最適ポートフォリオ過程の決定）は, 次節で行う. 会社は, 各時点 $t \in[0, T]$ での危険資産への投資単位数 $x(t)$, すなわちポートフォリオを管理することで, 時刻 $T$ の 持ち分 $\Pi_{E}(T)$ を最適化できるとする.

\section{1. 最適化問題の設定}

会社の目的を「時刻 $T$ での会社持ち分 $\Pi_{E}(T)$ について, 期待值一定のもとで, リスク（分 散）を最小にすること」とする．そこで， $\Pi_{A}(T)$ をコントロール変数とする最適化問題

$$
\begin{array}{ll}
\text { 最小化 } & \mathbb{E}^{P}\left[\left(\Pi_{E}(T)-\bar{\Pi}_{E}\right)^{2}\right], \\
\text { 条件 } & \mathbb{E}^{P}\left[\phi(T) \Pi_{A}(T)\right]=\Pi_{A}(0), \\
& \mathbb{E}^{P}\left[\Pi_{E}(T)\right]=: \bar{\Pi}_{E}: \text { 一定 }
\end{array}
$$

を考える3.

\footnotetext{
${ }^{3} \Pi_{A}(T)$ は自己资金調達取引戦略で実現できる．Karatzas 5 [10] 定理 3.3 .5 を参照.
} 
条件の 1 番目は, 命題 2.1 において $t=0$ とし, さらに(13) 式によって $P$ での期待值に書 き換えたものである。また，条件の 2 番目は， $\Pi_{E}(T)$ の期待值を定めることを表している.

(15) 式の最適化問題を, $\bar{\Pi}_{E}$ の值を変えながら解くと, リターンの期待値とリスクを 2 軸 にとった平面上での，実現可能領域の境界が得られる。この境界は，

・リスクー定の条件の下でリターンの期待值を最大にする部分，および

・リスク一定の条件の下でリターンの期待值を最小にする部分

からなる。このうち前者（効率的フロンティア）が，リスク回避的な投資家にとって意味を 持つ.

(5) 式より， $\Pi_{L}(T)$ は, 利率保証が適用され成果配当がない場合と, 成果配当がある場合 に分かれる．成果配当がある場合，

$$
\Pi_{L}(T)=\Pi_{L}(0)\left[1+\beta \frac{\Pi_{E}(T)+\Pi_{L}(T)}{\Pi_{A}(0)}-\beta\right]
$$

より,

$$
\Pi_{L}(T)=\frac{1}{b}\left[(1-b) \Pi_{E}(T)+(1-\beta) \Pi_{L}(0)\right]
$$

となる。ただし，

$$
b:=1-\beta \frac{\Pi_{L}(0)}{\Pi_{A}(0)}
$$

としたよって，配当のあるなしの境界は，(5) 式と (16)式より

$$
\begin{aligned}
e^{r_{g} T} & \geqq 1+\beta\left(\frac{\Pi_{A}(T)}{\Pi_{A}(0)}-1\right) \\
\Longleftrightarrow \Pi_{E}(T) & \leqq \bar{\Pi}_{E}-K
\end{aligned}
$$

と書ける。ただし，

$$
K:=\bar{\Pi}_{E}-\left(1+\frac{e^{r_{g} T}-1}{\beta}\right) \Pi_{A}(0)+e^{r_{g} T} \Pi_{L}(0)
$$

とした。

以上により，配当の有無による場合分けを反映した $\Pi_{L}(T)$ および $\Pi_{A}(T)$ は， $\Pi_{E}(T)$ の関 数として，それぞれ，

$$
\begin{aligned}
& \Pi_{L}\left(\Pi_{E}(T)\right)= \begin{cases}\Pi_{L}(0) e^{r_{g} T} ; & \Pi_{E}(T) \leq \bar{\Pi}_{E}-K \\
\frac{1-b}{b} \Pi_{E}(T)+\frac{1-\beta}{b} \Pi_{L}(0) ; & \Pi_{E}(T)>\bar{\Pi}_{E}-K\end{cases} \\
& \Pi_{A}\left(\Pi_{E}(T)\right)= \begin{cases}\Pi_{E}(T)+\Pi_{L}(0) e^{r_{g} T} ; & \Pi_{E}(T) \leq \bar{\Pi}_{E}-K \\
\frac{1}{b} \Pi_{E}(T)+\frac{1-\beta}{b} \Pi_{L}(0) ; & \Pi_{E}(T)>\bar{\Pi}_{E}-K\end{cases}
\end{aligned}
$$

と表現できる。したがって， $\Pi_{A}(T)$ をコントロール変数とする最適化問題 $(15)$ 式は, $\Pi_{E}(T)$ をコントロール変数とする最適化問題

最小化 $\mathbb{E}^{P}\left[\left(\Pi_{E}(T)-\bar{\Pi}_{E}\right)^{2}\right]$,

条件 $\quad \mathbb{E}^{P}\left[\phi(T)\left\{\left(\Pi_{E}(T)+\Pi_{L}(0) e^{r_{g} T}\right) 1_{\left\{\Pi_{E}(T) \leq \bar{\Pi}_{E}-K\right\}}\right.\right.$

$$
\begin{aligned}
& \left.\left.+\left(\frac{1}{b} \Pi_{E}(T)+\frac{1-\beta}{b} \Pi_{L}(0)\right) 1_{\left\{\Pi_{E}(T)>\bar{\Pi}_{E}-K\right\}}\right\}\right]=\Pi_{A}(0), \\
\mathbb{E}^{P}\left[\Pi_{E}(T)\right]= & \bar{\Pi}_{E}
\end{aligned}
$$


と書き直すことができる。

\section{2. 最適解}

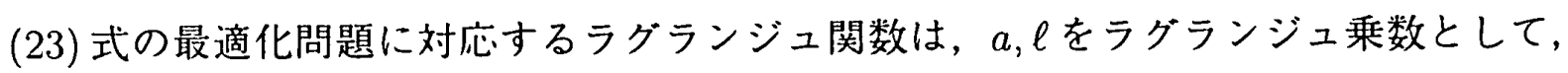

$$
\begin{aligned}
\mathcal{L}\left(\left\{\Pi_{E}(T)(\omega), \omega \in \Omega\right\}, a, \ell\right):= & \mathbb{E}^{P}\left[\left(\Pi_{E}(T)-\bar{\Pi}_{E}\right)^{2}\right] \\
& -\ell\left[\mathbb{E}^{P}\left[\phi(T) \Pi_{A}\left(\Pi_{E}(T)\right)\right]-\Pi_{A}(0)\right] \\
& -a\left[\mathbb{E}^{P}\left[\Pi_{E}(T)\right]-\bar{\Pi}_{E}\right] \\
= & \mathbb{E}^{P}\left[\left(\Pi_{E}(T)-\bar{\Pi}_{E}\right)^{2}\right. \\
& -\ell\left(\phi(T) \Pi_{A}\left(\Pi_{E}(T)\right)-\Pi_{A}(0)\right) \\
& \left.-a\left(\Pi_{E}(T)-\bar{\Pi}_{E}\right)\right]
\end{aligned}
$$

と書ける。このラグランジュ関数を用いて, 最適化問題 (23) 式を以下の手順で解く.

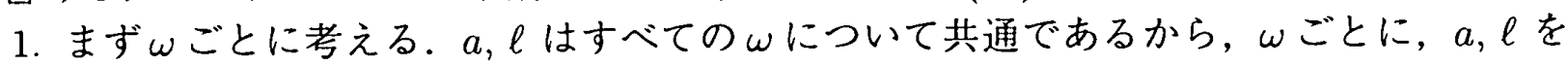
所与と考え, $\mathcal{L}\left(\left\{\Pi_{E}(T)(\omega), \omega \in \Omega\right\}, a, \ell\right)$ を最小にする $\Pi_{E}(T)(\omega, a, \ell)$ を求める ${ }^{4}$.さら に, $\Pi_{E}(T)(\omega, a, \ell)$ を実現する自己資金調達取引戦略を求める ${ }^{5}$.

2. 次に, $\Omega$ 全体について考える. 最適な $\Pi_{E}(T)(\omega, a, \ell)$, および最適化問題 (23) 式の条 件により, $a, \ell$ を求める ${ }^{6} . \omega こ ゙ と に ~\left(\Pi_{E}(T)-\bar{\Pi}_{E}\right)^{2}$ が最小となれば, 確率測度で積分 した期待值 $\mathbb{E}^{P}\left[\left(\Pi_{E}(T)-\bar{\Pi}_{E}\right)^{2}\right]$ も最小になる.

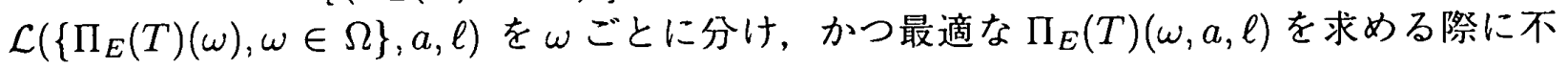
要な定数部分を除いて, 関数

$$
\begin{aligned}
& L\left(\Pi_{E}(T)\right):=\left(\Pi_{E}(T)-\bar{\Pi}_{E}\right)^{2}-a \Pi_{E}(T)-\ell \phi(T) \Pi_{A}\left(\Pi_{E}(T)\right) \\
& =\left\{\begin{aligned}
\left(\Pi_{E}(T)-\bar{\Pi}_{E}\right)^{2}-a \Pi_{E}(T) & \\
-\ell \phi(T)\left(\Pi_{E}(T)+\Pi_{L}(0) e^{r_{g} T}\right) ; & \Pi_{E}(T) \leq \bar{\Pi}_{E}-K, \\
\left(\Pi_{E}(T)-\bar{\Pi}_{E}\right)^{2}-a \Pi_{E}(T) & \\
-\ell \phi(T)\left(\frac{1}{b} \Pi_{E}(T)+\frac{1-\beta}{b} \Pi_{L}(0)\right) ; & \Pi_{E}(T)>\bar{\Pi}_{E}-K,
\end{aligned}\right. \\
& = \begin{cases}\left(X-\frac{a+\ell \phi(T)}{2}\right)^{2}+C_{1}=: L_{1}(X) ; \quad & X \leq-K \\
\left(X-\frac{a+\frac{1}{b} \ell \phi(T)}{2}\right)^{2}+C_{2}=: L_{2}(X) ; \quad X>-K\end{cases}
\end{aligned}
$$

を定義する。ただし，

$$
\begin{aligned}
X:= & \Pi_{E}(T)-\bar{\Pi}_{E}, \\
C_{1}:= & -(a+\ell \phi(T)) \bar{\Pi}_{E}-\left(\frac{a+\ell \phi(T)}{2}\right)^{2}-\ell \phi(T) \Pi_{L}(0) e^{r_{g} T}, \\
C_{2}:= & C_{1}+\left(1-\frac{1}{b}\right)\left(\bar{\Pi}_{E}+\frac{a}{2}+\left(1+\frac{1}{b}\right) \frac{\ell \phi(T)}{4}\right) \ell \phi(T) \\
& +\ell \phi(T) \Pi_{L}(0)\left(e^{r_{g} T}-\frac{1-\beta}{b}\right)
\end{aligned}
$$

\footnotetext{
${ }^{4} \omega$ は危険資産の変動経路を表す。保険会社は， $\omega$ ごとに，危険資産の変動経路に応してポートフォリオを 管理することで, $\Pi_{A}(T)$ を通じて $\Pi_{E}(T)$ を操作できる.

5 第 4 節を参照.

6 第 5 節を参照.
} 
とした， $\omega こ ゙ と に ~ \phi(T)$ は一定であり， $a, \ell$ を止めて考えているので, $L_{1}, L_{2}$ は $X$ すなわち $\Pi_{E}(T)$ だけの関数である. 本節では, $\Pi_{E}(T)$ は実数全体を動くものとする7 . (25) 式を最小 とする $\Pi_{E}(T)$ を $\Pi_{E}^{*}(T)$ とする。

このとき, 次が成り立つ。

定理 $3.1 \ell \geq 0$ の場合；

$$
\Pi_{E}^{*}(T)= \begin{cases}\bar{\Pi}_{E}+\frac{a}{2}+\frac{1}{b} \frac{\ell \phi(T)}{2} ; & -K<\frac{a}{2}+\frac{b+1}{2 b} \frac{\ell \phi(T)}{2}, \\ \bar{\Pi}_{E}+\frac{a}{2}+\frac{\ell \phi(T)}{2} ; & \frac{a}{2}+\frac{b+1}{2 b} \frac{\ell \phi(T)}{2} \leq-K,\end{cases}
$$

$\ell<0$ の場合 ;

$$
\Pi_{E}^{*}(T)= \begin{cases}\bar{\Pi}_{E}+\frac{a}{2}+\frac{1}{b} \frac{\ell \phi(T)}{2} ; & -K<\frac{a}{2}+\frac{1}{b} \frac{\ell \phi(T)}{2} \\ \bar{\Pi}_{E}-K ; & \frac{a}{2}+\frac{1}{b} \frac{\ell \phi(T)}{2} \leq-K<\frac{a}{2}+\frac{\ell \phi(T)}{2} \\ \bar{\Pi}_{E}+\frac{a}{2}+\frac{\ell \phi(T)}{2} ; & \frac{a}{2}+\frac{\ell \phi(T)}{2} \leq-K\end{cases}
$$

となる。

証明： $L_{1}(X)$ と $L_{2}(X)$ とは, $X^{2}$ の係数が等しく, $X=-K$ で交わる, 2 つの放物線であ る. $L_{1}(X)$ の頂点は, $\ell \geq 0$ のとき $L_{2}(X)$ の頂点の左側, $\ell<0$ のと $L_{2}(X)$ の頂点の右側 にくる．以上から，(25) 式で定義された $L\left(\Pi_{E}(T)\right)$ のグラフは，図 2 の太線で表される.

$L\left(\Pi_{E}(T)\right)$ を最小とする $X$ を $X^{*}$ とする. 図 2 の 6 個の場合分けのうち, 上下段左右の 4 個の場合では，太線上にある頂点の $X$ 座標が $X^{*}$ となる。 上段中央では, 2 個の頂点の $X$ 座 標のうち， $-K$ から遠い方が $X^{*}$ となる。下段中央では， $X^{*}=-K$ であ。したがって， $\ell \geq 0$ の場合 ;

$\ell<0$ の場合；

$$
X^{*}= \begin{cases}\frac{a}{2}+\frac{1}{b} \frac{\ell \phi(T)}{2} ; & -K<\frac{a}{2}+\frac{b+1}{2 b} \frac{\ell \phi(T)}{2} \\ \frac{a}{2}+\frac{\ell \phi(T)}{2} ; & \frac{a}{2}+\frac{b+1}{2 b} \frac{\ell \phi(T)}{2} \leq-K\end{cases}
$$

$$
X^{*}= \begin{cases}\frac{a}{2}+\frac{1}{b} \frac{\ell \phi(T)}{2} ; & -K<\frac{a}{2}+\frac{1}{b} \frac{\ell \phi(T)}{2}, \\ -K ; & \frac{a}{2}+\frac{1}{b} \frac{\ell \phi(T)}{2} \leq-K<\frac{a}{2}+\frac{\ell \phi(T)}{2}, \\ \frac{a}{2}+\frac{\ell \phi(T)}{2} ; & \frac{a}{2}+\frac{\ell \phi(T)}{2} \leq-K\end{cases}
$$

となる（図3）。よって，Xの定義 (26) 式により，(29) 式，(30)式が得られる.(証明終わり).

$\Pi_{L}^{*}(T):=\Pi_{L}\left(\Pi_{E}^{*}(T)\right), \Pi_{A}^{*}(T):=\Pi_{A}\left(\Pi_{E}^{*}(T)\right), V:=\left(\Pi_{E}^{*}(T)-\bar{\Pi}_{E}\right)^{2}$ とする. $\Pi_{E}^{*}(T)$,

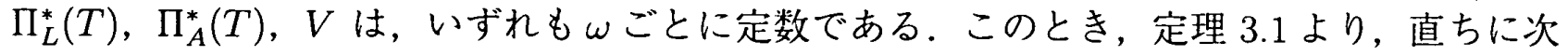
の 2 つの系が得られる.

系 $3.1 \ell \geq 0$ の場合;

$$
\begin{aligned}
\Pi_{A}^{*}(T) \equiv & \Pi_{E}^{*}(T)+\Pi_{L}^{*}(T) \\
= & \left\{\begin{array}{r}
\frac{1}{b}\left(K+\frac{a}{2}+\frac{\ell \phi(T)}{2}\right)+\Pi_{A}(0)\left(1+\frac{e^{r_{g} T}-1}{\beta}\right) ; \\
-K<\frac{a}{2}+\frac{b+1}{2 b} \frac{\ell \phi(T)}{2} \\
K+\frac{a}{2}+\frac{\ell \phi(T)}{2}+\Pi_{A}(0)\left(1+\frac{e^{r g} T-1}{\beta}\right) \\
\frac{a}{2}+\frac{b+1}{2 b} \frac{\ell \phi(T)}{2} \leq-K,
\end{array}\right.
\end{aligned}
$$

7このような $\Pi_{E}(T)$ が，自己資金調達取引戦略で実現できることについては，Karatzas ら [10] 定理 3.3 .5 を参照. 
$\ell<0$ の場合；

$$
\begin{aligned}
\Pi_{A}^{*}(T) \equiv & \Pi_{E}^{*}(T)+\Pi_{L}^{*}(T) \\
= & \left\{\begin{array}{cc}
\frac{1}{b}\left(K+\frac{a}{2}+\frac{\ell \phi(T)}{2}\right)+\Pi_{A}(0)\left(1+\frac{e^{r g} T-1}{\beta}\right) \\
\Pi_{A}(0)\left(1+\frac{e^{r_{g} T}-1}{\beta}\right) ; & -K<\frac{a}{2}+\frac{1}{b} \frac{\ell \phi(T)}{2} \\
K+\frac{a}{2}+\frac{\ell \phi(T)}{2}+\Pi_{A}(0)\left(1+\frac{\frac{l}{b} \frac{\ell(T)}{2} \leq-K<\frac{a}{2}+\frac{\ell \phi(T)}{2}}{\beta}\right) \\
\frac{a}{2}+\frac{\ell \phi(T)}{2} \leq-K
\end{array}\right.
\end{aligned}
$$

となる。

系 $3.2 \ell \geq 0$ の場合;

$$
V= \begin{cases}\left(\frac{a}{2}+\frac{1}{b} \frac{\ell \phi(T)}{2}\right)^{2} ; & -K<\frac{a}{2}+\frac{b+1}{2 b} \frac{\ell \phi(T)}{2} \\ \left(\frac{a}{2}+\frac{\ell \phi(T)}{2}\right)^{2} ; & \frac{a}{2}+\frac{b+1}{2 b} \frac{\ell \phi(T)}{2} \leq-K\end{cases}
$$

$\ell<0$ の場合 $;$

$$
V= \begin{cases}\left(\frac{a}{2}+\frac{1}{b} \frac{\ell \phi(T)}{2}\right)^{2} ; & -K<\frac{a}{2}+\frac{1}{b} \frac{\ell \phi(T)}{2} \\ K^{2} ; & \frac{a}{2}+\frac{1}{b} \frac{\ell \phi(T)}{2} \leq-K<\frac{a}{2}+\frac{\ell \phi(T)}{2} \\ \left(\frac{a}{2}+\frac{\ell \phi(T)}{2}\right)^{2} ; & \frac{a}{2}+\frac{\ell \phi(T)}{2} \leq-K\end{cases}
$$

となる。

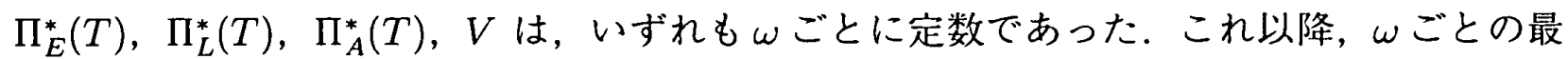
適值が既に求まったとして， $\omega$ を動かして， $\Pi_{E}^{*}(T), \Pi_{L}^{*}(T), \Pi_{A}^{*}(T), V$ を確率変数とする. $a$ と $\ell$ 符号について, 次の関係が成り立つ.

命題 $3.1 \ell>0$ ならば $a<0, \ell<0$ ならば $a>0, \ell=0$ ならば $a=0$ である.

証明： $X$ の定義より $\mathbb{E}^{P}\left[X^{*}\right]=0$ であるから, 図 3 より, $\ell>0$ ならば $a<0, \ell<0$ ならば $a>0, \ell=0$ ならば $a=0$ となる（証明終わり）.

$\mathcal{V}$ を $\Pi_{E}^{*}(T)$ の観測確率測度 $P$ での分散，すなわち

$$
\begin{aligned}
\mathcal{V} & :=\mathbb{E}^{P}\left[\left(\Pi_{E}^{*}(T)-\bar{\Pi}_{E}\right)^{2}\right] \\
& =\mathbb{E}^{P}[V]
\end{aligned}
$$

とすると，次が成り立つ。

\section{命題 3.2}

$$
\frac{d \mathcal{V}}{d \bar{\Pi}_{E}}=a
$$




\section{証明:}

$\ell<0$ すなわち $a>0$ とする. Vを $a, \ell, \bar{\Pi}_{E}$ の関数と考え,

$$
\mathcal{V}^{\prime}:=\frac{d \mathcal{V}}{d \bar{\Pi}_{E}}, \quad a^{\prime}:=\frac{d a}{d \bar{\Pi}_{E}}, \quad \ell^{\prime}:=\frac{d \ell}{d \bar{\Pi}_{E}},
$$

とする。また，

$$
\mathcal{A}:=\left\{\omega \in \Omega ; K+\frac{a+\frac{\ell}{b} \phi(T)}{2}>0\right\}, \mathcal{B}:=\left\{\omega \in \Omega ; K+\frac{a+\ell \phi(T)}{2}<0\right\}
$$

とする.このとき，(30)式より，

$$
\frac{d}{d \bar{\Pi}_{E}} \mathbb{E}^{P}\left[\left(K+\frac{a+\frac{\ell}{b} \phi(T)}{2}\right) 1_{\mathcal{A}}+\left(K+\frac{a+\ell \phi(T)}{2}\right) 1_{\mathcal{B}}\right]=1 .
$$

同様に，(34) 式から，

$$
\frac{d}{d \bar{\Pi}_{E}} \mathbb{E}^{P}\left[\phi(T)\left(\frac{1}{b}\left(K+\frac{a+\frac{\ell}{b} \phi(T)}{2}\right) 1_{\mathcal{A}}+\left(K+\frac{a+\ell \phi(T)}{.2}\right) 1_{\mathcal{B}}\right)\right]=0 .
$$

したがって，

$$
\begin{aligned}
\mathcal{V}^{\prime}= & 2 K+\left(\frac{a^{\prime}}{2}-1\right) \mathbb{E}^{P}\left[\left(K+\frac{a+\frac{\ell}{b} \phi(T)}{2}\right) 1_{\mathcal{A}}+\left(K+\frac{a+\ell \phi(T)}{2}\right) 1_{\mathcal{B}}\right] \\
& +\frac{\ell^{\prime}}{2} \mathbb{E}^{P}\left[\phi(T)\left(\frac{1}{b}\left(K+\frac{a+\frac{\ell}{b} \phi(T)}{2}\right) 1_{\mathcal{A}}+\left(K+\frac{a+\ell \phi(T)}{2}\right) 1_{\mathcal{B}}\right)\right] \\
& +\left(\frac{a}{2}-K\right) \\
= & a .
\end{aligned}
$$

$\ell>0$ すなわち $a<0$ のときも, 同様に $\mathcal{V}^{\prime}=a$ が示される. さらに, $\ell=0$ すなわち $a=0$ とすると, $\Pi_{E}^{*}(T)=\bar{\Pi}_{E}:$ 一定より

$$
\mathcal{V}=\mathbb{E}^{P}\left[\left(\Pi_{E}^{*}(T)-\bar{\Pi}_{E}\right)^{2}\right]=0 .
$$

よって $\mathcal{V}^{\prime}=0=a$ となる（証明終わり）.

命題 3.2 から, 実現可能領域の境界のうち, $a>0$ はリスク一定の条件の下でリターンの 期待值が最大となる部分， $a<0$ はリスク一定の条件の下でリターンの期待值が最小となる 部分に対応する（図 4).リスク回避的な投資家にとって意味を持つのは, リターンの期待 值を最大にする部分（効率的フロンティア）であるから，以下では $a>0$ とする.

\section{4. 最適運用戦略と効率的フロンティア}

この節では, マルチンゲール法の第 2 段階である, 最適ポートフォリオ過程の決定を行う. すなわち，(34) 式の $\Pi_{A}(t)$ を実現する，危険資産への投資単位数の過程 $\{x(t) ; t \in[0, T]\}$ を 求める. 会社は, 資産運用において, この $\{x(t) ; t \in[0, T]\}$ を採用すると, $(15)$ 式の最適化 を実現できる，さらに，この節では，効率的フロテンティアを書く方法について述べる. 
$\ell \geq 0$ の場合;
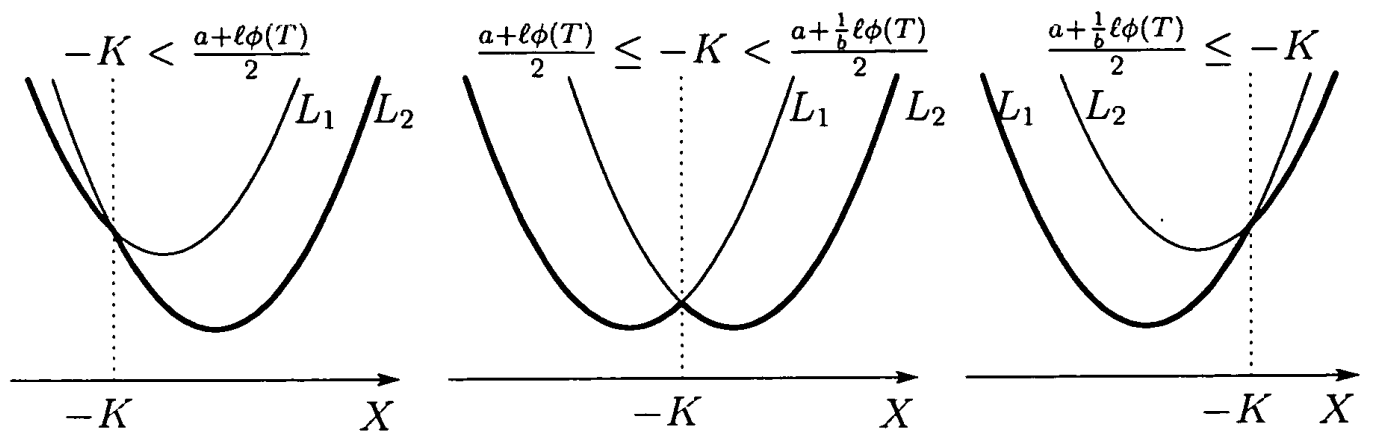

$\ell<0$ の場合;
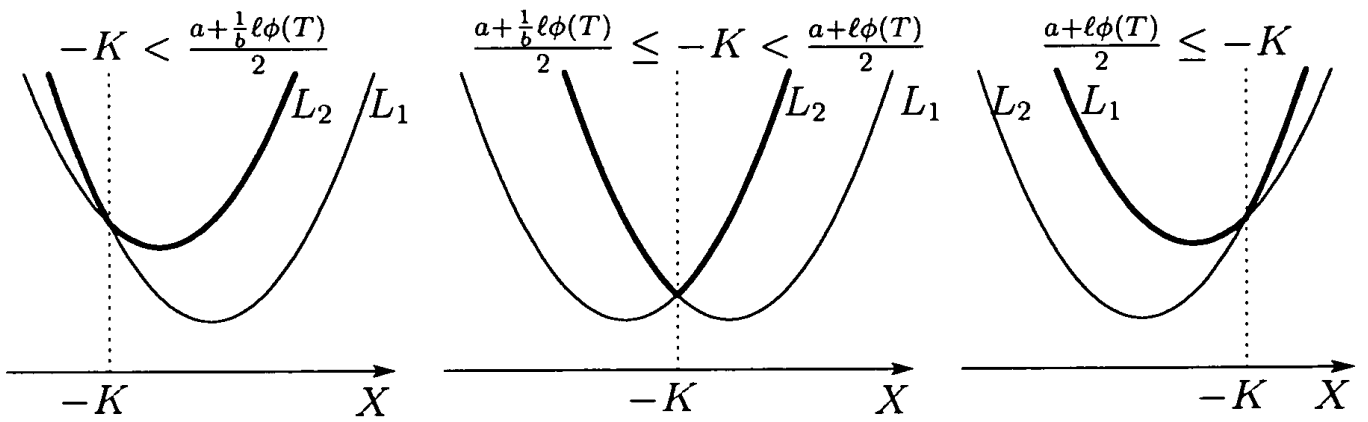

図 2: $L_{i}(X)$
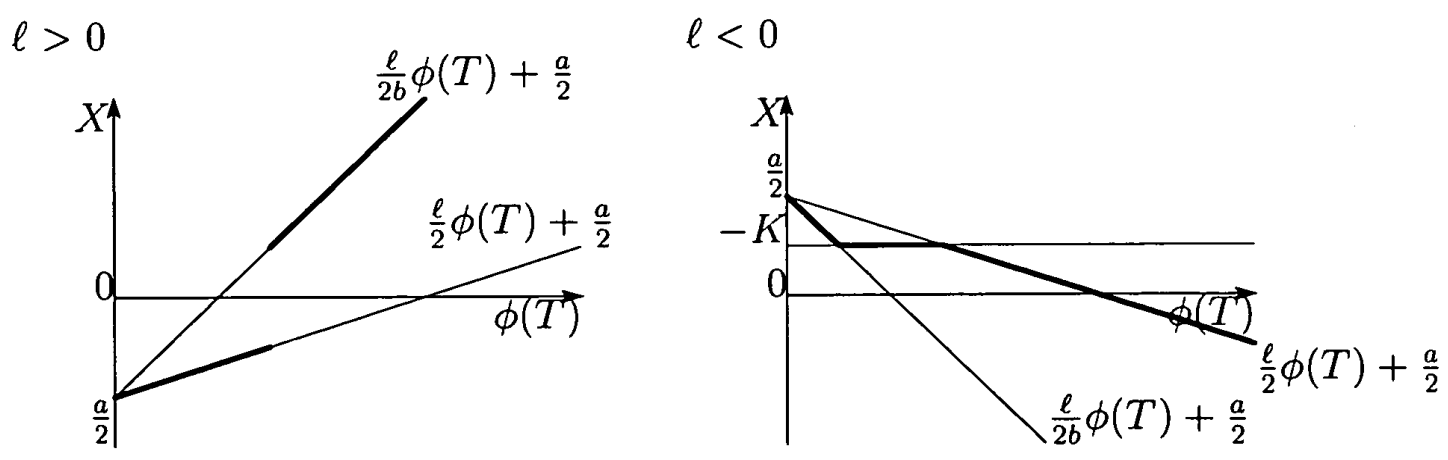

図 3: 最適な $X$

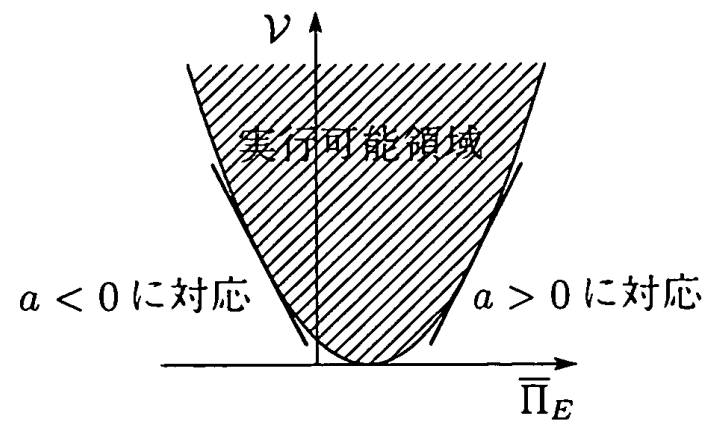

図 4: 実行可能境界と $a$ の符号 


\section{1. 最適運用戦略}

$\Pi_{A}^{*}(T)$ を達成するポートフォリオ過程を $\left\{x^{*}(t) ; t \in[0, T]\right\}$ とすると, 次の定理が成り立つ. 定理 4.1

$$
x^{*}(t)=\frac{e^{-r_{f}(T-t)} \mathcal{Y}(t)}{S(t) \sigma}, \quad t \in[0, T]
$$

となる。ただし，

$$
\begin{aligned}
\mathcal{Y}(t):=- & \frac{\ell \xi}{2} \phi(t) e^{\left(\xi^{2}-r_{f}\right)(T-t)} \\
& \times\left(\frac{1}{b^{2}}\left(1-\Phi\left(d_{2}(t)+\xi \sqrt{T-t}\right)\right)+\Phi\left(d_{1}(t)+\xi \sqrt{T-t}\right)\right)
\end{aligned}
$$

であり, $\Phi(x)$ は標準正規分布の分布関数で,

$$
\begin{aligned}
d_{1}(t) & :=\frac{\ln \left(\frac{\ell \phi(t)}{-2 K-a}\right)+\left(\frac{1}{2} \xi^{2}-r_{f}\right)(T-t)}{\xi \sqrt{T-t}}, \\
d_{2}(t) & :=\frac{\ln \left(\frac{\ell \phi(t)}{b(-2 K-a)}\right)+\left(\frac{1}{2} \xi^{2}-r_{f}\right)(T-t)}{\xi \sqrt{T-t}}
\end{aligned}
$$

である。

証明：(34)式より，リスク中立確率測度 $Q$ の下での $\Pi_{A}(T)$ の条件付き期待値 $\mathbb{E}_{t}^{Q}\left[\Pi_{A}^{*}(T)\right], t \in$ $[0, T]$ は,

$$
\begin{aligned}
\mathbb{E}_{t}^{Q}\left[\Pi_{A}^{*}(T)\right]= & \frac{1}{b}\left((1-\beta) \Pi_{L}(0)+\bar{\Pi}_{E}+\frac{a}{2}\right) \\
& -\frac{1}{b}\left(K+\frac{a}{2}\right) \Phi\left(d_{2}(t)\right) \\
& +\left(K+\frac{a}{2}\right) \Phi\left(d_{1}(t)\right) \\
& +\frac{\ell}{2 b^{2}} \phi(t) e^{\left(\xi^{2}-r_{f}\right)(T-t)}\left(1-\Phi\left(d_{2}(t)+\xi \sqrt{T-t}\right)\right) \\
& +\frac{\ell}{2} \phi(t) e^{\left(\xi^{2}-r_{f}\right)(T-t)} \Phi\left(d_{1}(t)+\xi \sqrt{T-t}\right)
\end{aligned}
$$

となる.よって，

$$
Y(t):=\mathbb{E}_{t}^{Q}\left[\Pi_{A}^{*}(T)\right]
$$

とすると, 伊藤の公式を使って，

$$
d Y(t)=\mathcal{Y}(t)(d W(t)+\xi d t)
$$

が得られる。したがって，

$$
\begin{aligned}
d \Pi_{A}^{*}(t) & =d\left(e^{-r_{f}(T-t)} Y(t)\right) \\
& =r_{f} \Pi_{A}^{*}(t) d t+e^{-r_{f}(T-t)} d Y(t) \\
& =r_{f} \Pi_{A}^{*}(t) d t+e^{-r_{f}(T-t)} \mathcal{Y}(t)(d W(t)+\xi d t)
\end{aligned}
$$


となる。一方，(4)式より，

$$
d \Pi_{A}^{*}(t)=r_{f} \Pi_{A}^{*}(t) d t+x(t) S(t) \sigma(d W(t)+\xi d t)
$$

である。したがって，(52) 式と (53) 式の係数を比較することによって，(45) 式が得られる (証明終わり).

\section{2. 効率的フロテンティア}

株主持ち分のリターンの期待値 $\overline{R^{*}}$ は

$$
\overline{R^{*}}:=\frac{\mathbb{E}^{P}\left[\Pi_{E}^{*}(T)\right]-\Pi_{E}(0)}{\Pi_{E}(0)}
$$

で得られる。ただし， $\mathbb{E}^{P}\left[\Pi_{E}^{*}(T)\right]$ は $(30)$ 式から，

$$
\begin{aligned}
\mathbb{E}^{P}\left[\Pi_{E}^{*}(T)\right]= & \bar{\Pi}_{E}+\frac{a}{2} \\
& -\left(K+\frac{a}{2}\right) \Phi\left(d_{2}(0)-\xi \sqrt{T}\right) \\
& +\left(K+\frac{a}{2}\right) \Phi\left(d_{1}(0)-\xi \sqrt{T}\right) \\
& +\frac{\ell}{2 b} \phi(0) e^{-r_{f} T}\left(1-\Phi\left(d_{2}(0)\right)\right) \\
& +\frac{\ell}{2} \phi(0) e^{-r_{f} T} \Phi\left(d_{1}(0)\right)
\end{aligned}
$$

となる。一方，リスク（リターンの標準偏差） $\sigma_{R}^{*}$ は,

$$
\sigma_{R}^{*}:=\frac{\mathcal{V}^{1 / 2}}{\Pi_{E}(0)}
$$

となる。ただし，Vは(30)式から，

$$
\begin{aligned}
\mathcal{V}= & \frac{a^{2}}{4}\left(1-\Phi\left(d_{2}(0)-\xi \sqrt{T}\right)\right) \\
& +\frac{a \ell}{2 b} \phi(0) \exp \left(-r_{f} T\right)\left(1-\Phi\left(d_{2}(0)\right)\right) \\
& +\frac{\ell^{2}}{4 b^{2}}(\phi(0))^{2} \exp \left(\left(\xi^{2}-2 r_{f}\right) T\right)\left(1-\Phi\left(d_{2}(0)+\xi \sqrt{T}\right)\right) \\
& +K^{2}\left(\Phi\left(d_{2}(0)-\xi \sqrt{T}\right)-\Phi\left(d_{1}(0)-\xi \sqrt{T}\right)\right) \\
& +\frac{a^{2}}{4} \Phi\left(d_{1}(0)-\xi \sqrt{T}\right) \\
& +\frac{a \ell}{2} \phi(0) \exp \left(-r_{f} T\right) \Phi\left(d_{1}(0)\right) \\
& +\frac{\ell^{2}}{4}(\phi(0))^{2} \exp \left(\left(\xi^{2}-2 r_{f}\right) T\right) \Phi\left(d_{1}(0)+\xi \sqrt{T}\right)
\end{aligned}
$$

となる. 命題 3.2 から， $a>0$ のとき「リターンの期待値が増えるとリスクが増える」とい う関係があることが分かるから，次の手続きによって，効率的フロンティアが得られる.

1. $\bar{\Pi}_{E}$ の值を変えながらラグランジュ乗数 $a$ と $\ell$ を求める.

2. 得られた $a$ と $\ell$ を使って $\Pi_{E}^{*}(T)$ を求め, リターンの期待值をリスクを計算する.

3. リターンの期待值とリスクを 2 軸とする平面上に, 計算結果をプロットする. 


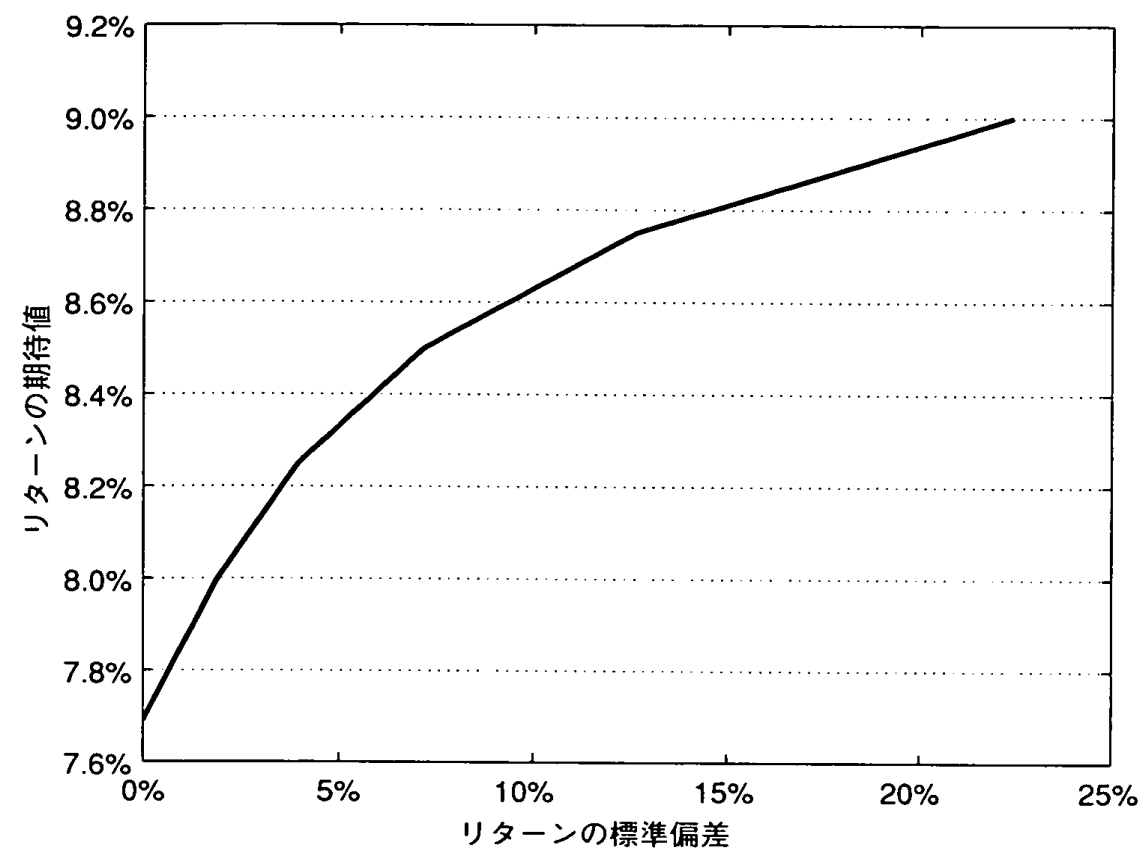

図 5: 効率的フロンティア

\section{5. 数值計算}

ラグランジュ乗数 $a$ と

$$
\begin{aligned}
\frac{\Pi_{A}(0)}{B(0)} & =\mathbb{E}^{Q}\left[\frac{\Pi_{A}^{*}(T)}{B(T)}\right] \\
\bar{\Pi}_{E} & =\mathbb{E}^{P}\left[\Pi_{E}^{*}(T)\right]
\end{aligned}
$$

を満たす。ただし，(58) 式，(59) 式から解析的に $a$ と $\ell$ を解くのは難しいので, 数值計算を 行う.

前提条件として, $T=1, r_{f}=0.05, r_{g}=0.03, B(0)=1, S(0)=1, \mu=0.1, \sigma=$ $0.3, \beta=0.9, \Pi_{A}(0)=1.2, \Pi_{L}(0)=1.0, \overline{R^{*}}=0.08$ とする.また $\ell<0$ とする.以上によ $\eta,(49)$ 式, (55) 式, (58) 式, (59) 式を使って, $a=0.052, \ell=-0.014$ を得る.さらに, こ れらの結果と，(56) 式，(57) 式により， $\sigma_{R}^{*}=0.019$ を得る。 $\overline{R^{*}}$ だけを 0.09 とし，他の条件 は上記と同様とすると， $\sigma_{R}^{*}=0.224$ が得られる．以上のよう $\bar{R}^{*}$ を変えながら，対応する $\sigma_{R}^{*}$ を繰り返し計算することにより，効率的フロンティアを得る（図 5）。

次に, $\overline{R^{*}}, r_{g}, \beta$ の変化による, $x^{*}(0)$ に対する影響を調べる. 他の条件は, 上記と同様 とし， $\overline{R^{*}}$ を変えながら， $x^{*}(0)$ を数值計算することにより，図 6 を得る。同図から, $\overline{R^{*}}$ が 増えると $x^{*}(0)$ も増える関係があり，高い期待収益率を設定すると危険資産への投資比率が 高まることが，見て取れる。

$r_{g}$ を変えながら $x^{*}(0)$ を数值計算して, 図 7 を得る. $r_{g}$ は, $x^{*}(0)$ にそれほど影響しない. $r_{g}$ の変化に比べて，いわゆる行使価格である $\Pi_{L}(0) e^{r_{g} T}$ の変化が大きくないためであろう.

$\beta$ を変えながら $x^{*}(0)$ を数值計算して, 図 8 を得る. $\beta$ が增えると $x^{*}(0)$ も増える関係が ある. 契約者への払い出し比率が高まると会社持ち分が減り，それを補うために危険資産へ の投資比率が高まるためであろう。

続いて，配当する確率について調べる，他の条件は，上記と同様とし， $\overline{R^{*}}$ 変えながら， 


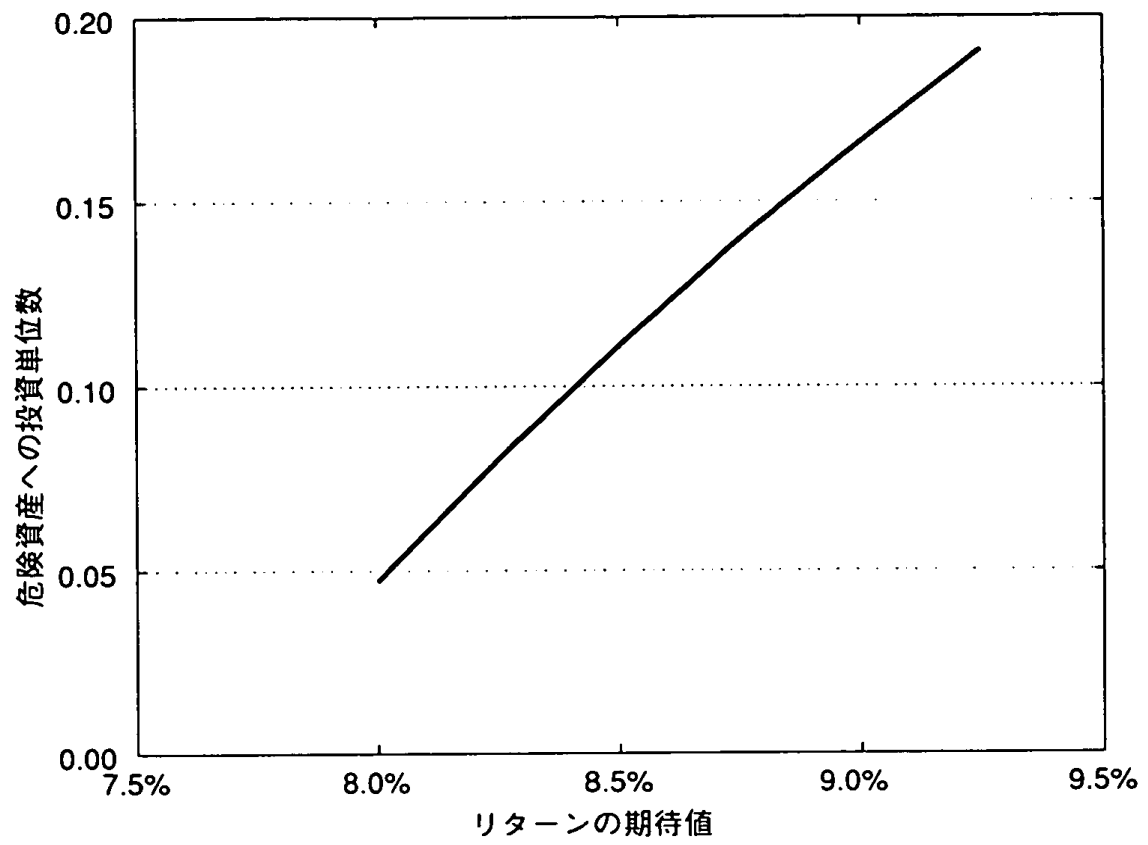

図 6: リターンの期待值 $\overline{R^{*}}$ と危険資産への投資単位数 $x^{*}(0)$

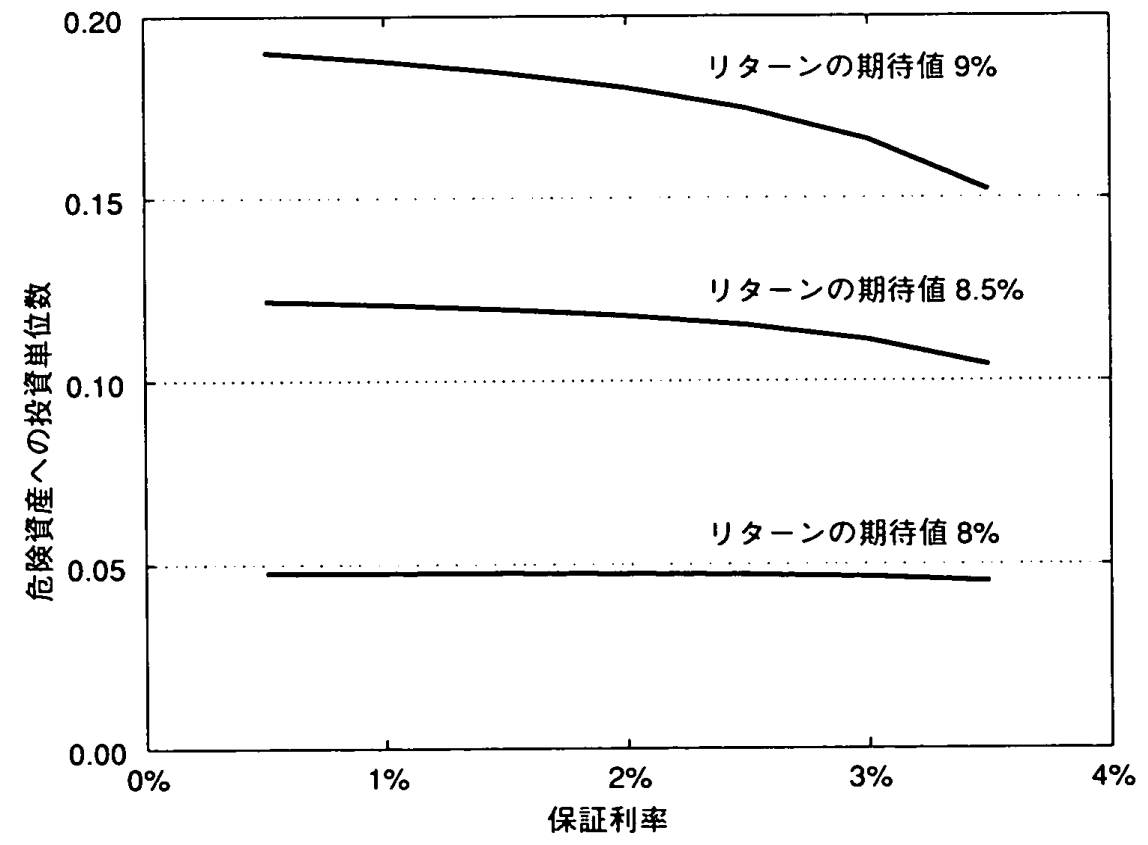

図 7: 保証利率 $r_{g}$ と危険資産への投資単位数 $x^{*}(0)$ 


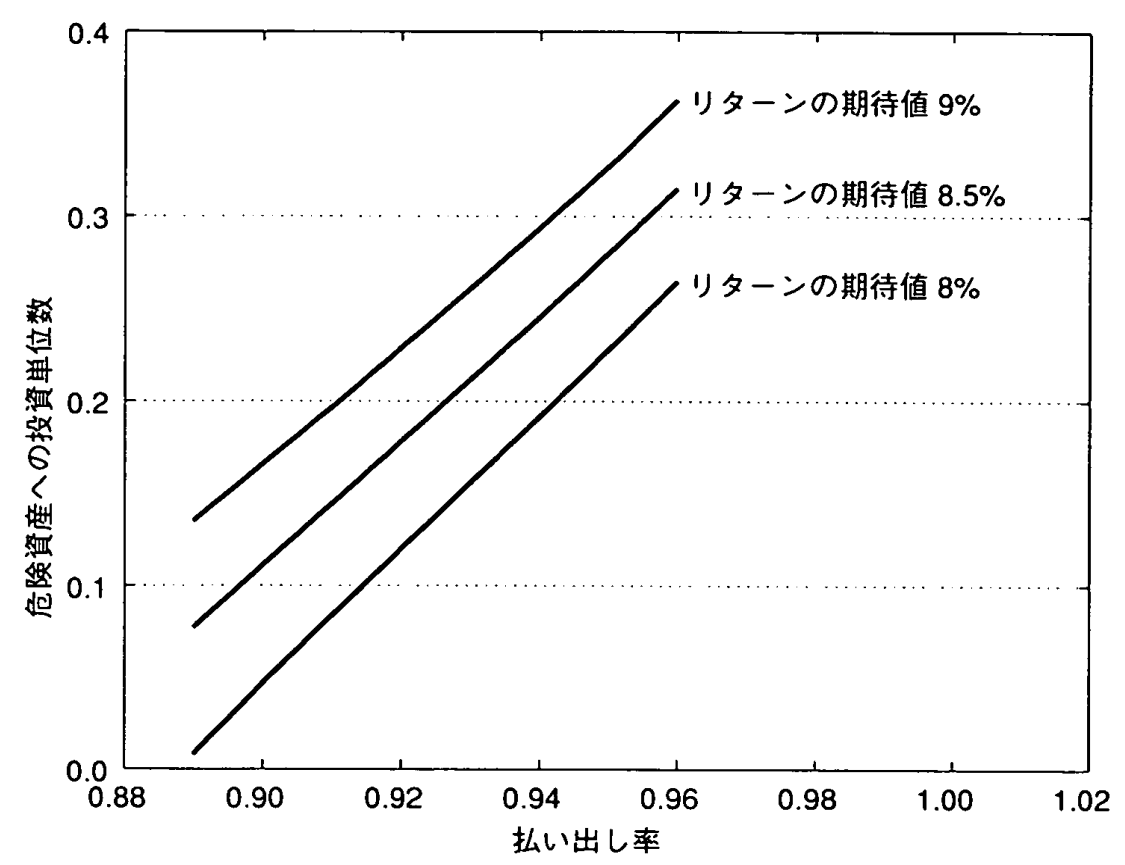

図 8: 払い出し率 $\beta$ と危険資産への投資単位数 $x^{*}(0)$

配当確率を計算した（図 9）。試算の条件下， $\overline{R^{*}}$ が $8 \%$ では，配当確率は $80 \%$ ほどである.

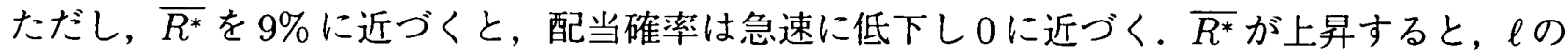
絶対值（図 3 の $X(\phi(T))$ の傾き）が急になり，有配当に対応する領域が狭くなる.

\section{6. おわりに}

本研究では，年金保険商品を，「会社の運用資産を原資産とする，コールオプション類似 の条件付き請求権」としてモデル化した．期末の運用資産を会社持ち分と契約者持ち分に分 け，さらに無裁定条件を課して，マルチンゲール法により，会社持ち分の最適化（収益率の 分散最小化）を行い，それを実現する資産ポートフォリオ過程を得た。さらに，数值計算に よって，会社持ち分の効率的フロンティアを得た。その結果，期末の資産価値を表す式は， 危険資産の期末の価格に応じて，3つの区間に分かれることが分かった。ささに，本論文で 設定した諸条件の下での最適戦略では，配当する確率が正になることが分かった。

今後の残された研究課題としては, 以下があげられる。まず, 経済的な比較静学を行うこ と，たとえば，最適ポートフォリオの解析的な性質を調べることである．また，分散最小化 以外の基準で最適化した場合について，調べる必要がある．分散最小化が意味を持つのは， 限られた条件下に限られるからである. 複数回配当のモデルへの組み込みも課題である. 年 金保険商品には,「複数年契約で，契約が継続しながら，毎年，成果配当が行われる」という 特徽があるが，今回のモデルでは，これを反映せず，成果配当を 1 回限りとしている，さら に，契約者持ち分の最適化を考えることも有益だろう。その場合，契約者の効用を考え，そ れを最大化するための保険会社へのインセンティブの付与の方法, すなわち, 保険会社に対 してどのような成果配分ルールを課すのが望ましいかを考察することも重要な課題となる.

年金制度は，今後の社会を支える上で，重要性をさらに増している。より効率的な制度運 用へ向けての，一層の研究が期待される。 


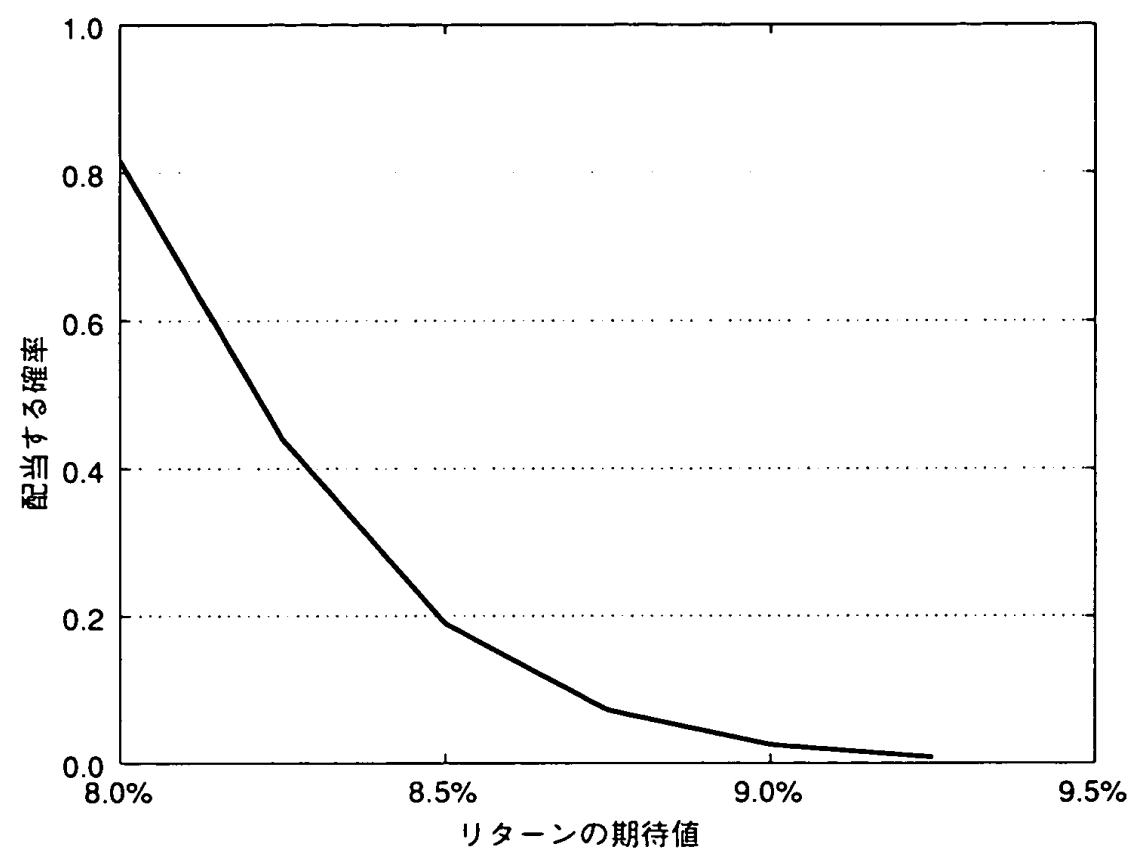

図 9: リターンの期待值 $\overline{R^{*}}$ と配当する確率

\section{謝辞}

本稿をまとめるにあたり, 多くの貴重なご意見をくださった京都大学岩城秀樹助教授, 及 び重要な論点を指摘してくださった匿名の査読者に，この場をかりて感謝いたします。

\section{参考文献}

[1] K. K. Aase and S. -A. Persson: Pricing of unit-linked life insurance policies. Scandinavian Actuarial Journal, 1 (1994) 26-52.

[2] A. R. Bacinello: Fair pricing of life insurance participating policies with a minimum interest rate guaranteed. AFIR 2000 proceedings, 1-28.

[3] F. Black and M. Scholes: The pricing of options and corporate liabilities. Journal of Political Economy, 81 (1973) 637-654.

[4] M. J. Brennan and E. S. Schwartz: The pricing of equity-linked life insurance policies with an asset value guarantee. Journal of Financial Economics, 3 (1976) 195-213.

[5] C. Giraldi, G. Susinno, G. Berti, J. Brunello, S. Buttarazzi, G. Cenciarelli, C. Daroda and G. Stamegna: Insurance optional. Risk, 13-4 (2000) 87-90.

[6] A. Grosen and P. L. Jørgensen: Fair valuation of life insurance liabilities: The impact of interest rate guarantees, surrender options, and bonus policies. Insurance: Mathematics and Economics, 26-1 (2000) 37-57.

[7] J. M. Harrison and S. R. Pliska: Martingales and stochastic integrals in the theory of continuous trading. Stochastic Processes and their Applications, 11 (1981) 215-260.

[8] 岩城秀樹: ファイナンス講座 3 デリバティブ一理論と応用一(朝倉書店, 1998).

[9] B. Jensen, P. L. Jørgensen and A. Grosen: A finit difference approach to the valuation of path dependend life insurance liabilities. The Geneva Papers on Risk and Insurance 
Theory, 26-1 (2001) 57-84.

[10] I. Karatzas and S. E. Shreve: Methods of Mathematical Finance (Springer, New York, 1998).

[11] 木島正明: シリーズ <現代金融工学 $>3$ 期間構造モデルと金利デリバティブ (朝倉書 店, 1999).

[12] K. R. Miltersen and S. -A. Persson: Guaranteed investment contract: Distributed and undistributed cxcess return. AFIR 1999 proceedings, 281-301.

[13] J. A. Nielsen and K. Sandmann: Equity-linked life insurance: A model with stochastic interest rates. Insurance: Mathematics and Economics, 16-3 (1995) 225-253.

[14] S. R. Pliska: Introduction to Mathematical Finance Discrete Time Modles (Blackwell, Oxford, 1997).

[15] 湯前祥二: 準乱数による最低利率保証及び成果配当付き貯蓄商品の価格評価. 日本金 融・証券計量・工学学会 1996 年冬季大会予稿集 119-129.

[16] 湯前祥二, 鈴木輝好: シリーズ<現代金融工学 $>6$ モンテカルロ法の金融工学への応 用 (朝倉書店, 2000).

\footnotetext{
湯前祥二

ニッセイ基礎研究所 金融研究部門

干 100-0006 東京都千代田区有楽町一丁目 1 番 1 号

E-mail : yumae@nli-research.co.jp
} 


\begin{abstract}
AN OPTIMAL TRADING STRATEGY FOR PARTICIPATING POLICIES

\author{
Shoji Yumae \\ NLI Research Institute
}

I consider a participating policy as a contingent claim whose payoff is similar to a call option. The underlying asset of the claim is an asset portfolio continuously controlled by an insurance company. I derive an efficient frontier of the equity return of the company, as well as the trading strategy to realize efficient portfolios, by utilizing the martingale method for optimal portfolio selection problems. Some numerical examples indicate that the higher expected rate of return of the company is required, the more investment in risky assets is needed, and that probability of bonus payment is positive.
\end{abstract}

